\title{
"Loving Couples and Families:" Assimilation as Honorary Whiteness and the Making of the Vietnamese Refugee Family
}

\author{
Linh Thủy Nguyễn (D) \\ Department of American Ethnic Studies, University of Washington, Seattle, WA 98195-4380, USA; \\ lnguye@uw.edu
}

check for

updates

Citation: Nguyễn, Linh Thủy. 2021.

"Loving Couples and Families:"

Assimilation as Honorary Whiteness and the Making of the Vietnamese Refugee Family. Social Sciences 10: 209. https://doi.org/10.3390/ socsci10060209

Academic Editors: Pawan H. Dhingra and Tanya Golash-Boza

Received: 16 March 2021

Accepted: 27 May 2021

Published: 2 June 2021

Publisher's Note: MDPI stays neutral with regard to jurisdictional claims in published maps and institutional affiliations.

Copyright: (C) 2021 by the author. Licensee MDPI, Basel, Switzerland. This article is an open access article distributed under the terms and conditions of the Creative Commons Attribution (CC BY) license (https:/ / creativecommons.org/licenses/by/ $4.0 /)$.

\begin{abstract}
Integration studies of Vietnamese refugees and their children begin with the problem of assimilation based on cultural and racial difference and ultimately lead these groups to achieve upward mobility against great odds. While scholars have offered alternatives to linear models of assimilation which assume a prescribed path to determine when migrants become integrated, the ideologies and norms which underlie the so-called problem of assimilation remain largely unexamined. Building from a feminist and Foucauldian analysis of power, this article examines state-sponsored knowledge production, such as semi-annual government surveys of Vietnamese refugees as representations which reproduce and reinforce logics of heteronormativity and white supremacy. I contextualize the production of these social science surveys as legibility projects in the geopolitical context of international (Cold War) and domestic (state attempts to dismantle black power movements through civil rights) maintenance of white supremacy. By examining self-sufficiency surveys of Vietnamese refugees conducted upon arrival to the US from the 1970s-1980s and 1990s studies of the second generation, I argue that the family is an instrumental yet overlooked dimension of the racialization of Vietnamese as new immigrants which is rooted in heteronormative, Orientalist, and anti-black notions of family.
\end{abstract}

Keywords: Vietnamese refugees; critique of integration; resettlement; assimilation; refugee racialization; racial family; sociological containment

\section{Introduction}

"I couldn't imagine what the refugees would look like," said Taft ... the door opened and out stepped the first family: a handsome man, his gorgeous wife dressed in a long, flowing, flowered Vietnamese ao dai, and three polite, wellgroomed children. They were followed by another equally attractive family, and then another. The crowd responded with admiration. (Thompson 2010, p. 77)

Diplomat and refugee worker Larry Clinton Thompson describes the arrival of the first Vietnamese on 28 May 1975 to Fort Indiantown Gap, PA and the response of Julia Taft, head of the newly formed Interagency Taskforce for Indochina Refugees. In the photo above, a different but similarly gorgeous, polite Vietnamese family steps off a bus at Fort Chaffee, AR in 1975. Under Operation New Life/New Arrivals the US Army managed 130,000 refugees, one of the single largest evacuation and resettlement efforts in the United States to date. Refugees arrived by way of temporary staging centers in Guam and Wake Island, unincorporated US territories in the Pacific to be processed through one of the four temporary domestic refugee camps in California, Florida, Pennsylvania, and Arkansas mandated by the Indochina Migration Act in response to the chaotic exodus following the "Fall of Saigon." Officials imagined that the refugee situation would be resolved quickly with the camps slated to close by December 1975, 7 months after the first one opened.

In the anxious moments before the first Vietnamese arrived Taft quoted the former commandant of the Marine Corps and the head of the INS Leonard F. Chapman, Jr.: "When I went up to Indiantown Gap I was sure the Vietnamese refugees were going to carry spears 
and wear no clothes. When I saw these people and I realized what loving couples and families they were, I was so proud of my country and I knew that we should do everything we could to help them" (Thompson 2010, p. 77). Thompson remarked, "for Taft, the visit to Indiantown Gap and the reaction of Chapman was the moment she knew that the resettlement program for Vietnamese could succeed" (ibid). Taft's reference to Chapman's surprise reveals the dominant racialization of these relatively unfamiliar Southeast Asians as uncivilized savages. Carrying spears and wearing no clothes, before and during the American War, these Vietnamese suddenly transform and arrive as modern American subjects simply by stepping off a bus in Arkansas. What sort of alchemy does the family perform in its ability to transform savages into loving couples and families deserving of humanitarian largesse? I start with this image (Figure 1, (1970-1980 UC Irvine, Southeast Asian Archive. http:/ / ark.cdlib.org/ark:/13030/hb2x0nb10scui-ucid-sea025-002 (accessed on 25 January 2016))). to ask how conceptions and representations of family produce and reinforce modes of dominant knowledge and knowledge production. How did this beautiful family become an instrument for cordoning off of a history of imperialism and racial capitalism, instead coming to exemplify the potentialities of assimilation in America?

In 1975, the refugee status in the United States simultaneously afforded Vietnamese access to social services denied to immigrants and subjected them to state-funded documentation. ${ }^{1}$ The scale of government and military involvement in the Vietnamese refugee resettlement has contributed to their status as "overdocumented" in government data collection and assimilation-based studies (Rumbaut 1995). The success of Vietnamese refugees in the wake of involuntary migration has been repeatedly cited as proof of integration and assimilation by government surveys and academic research (Liu 1979; Finnan 1981; Rumbaut and Ima 1987). ${ }^{2}$ Scholars have focused on the figure of the refugee as an object of rescue and its use to justify humanitarian violence, empire and ongoing warfare (Nguyen 2012); in particular, Yến Lê Espiritu's critical refugee studies situates itself as a critique of the objectifying tendencies of problem-oriented analyses of the Vietnamese and a call to re-center the war as the conditions of possibility for refugee resettlement (Espiritu 2006). Espiritu focuses on how military efforts were redirected towards resettlement as humanitarian successes, demonstrating how resettlement was an extension of US foreign policy. Thus, the rescue produced the discourse of Vietnamese as "good refugees" which reframed the war as justified in light of US failure. While scholars have re-focused on the imperial dimensions abroad to "lin[k] the modern US racial state to the modern US empire," I focus on the domestic dimension as another front of the Cold War (ibid, p. 419). What is the significance of the consistent framing of the Vietnamese as heteronormative families in the context of racialized poverty experienced by black and Latinx families in the 1970s and 1980s? Rather than taking for granted that Vietnamese became another immigrant group to be included in the melting pot, I trace the methods of naturalizing refugees as immigrants through a sociological study. The "good refugee" figure is made possible within the configuration of the heteronormative family. While Asian racialization in the United States has been produced through the multiple axes of empire and war, and labor migration (Okihiro 2014), my focus on the family as a discursive structure is significant against the historical Orientalized representation of Vietnamese as naturally lazy, impoverished, dirty, primitive, effeminate, and weak in the interwar period (WWI-WWII) (Bradley 2000, pp. 47-58). The framing of the family as a site of cultural capital and value marks a shift in the racialization of Vietnamese as yet to be Asian Americans consistent with "positive" model minorityracialization ${ }^{3}$ after WWII (Lee 1999). 


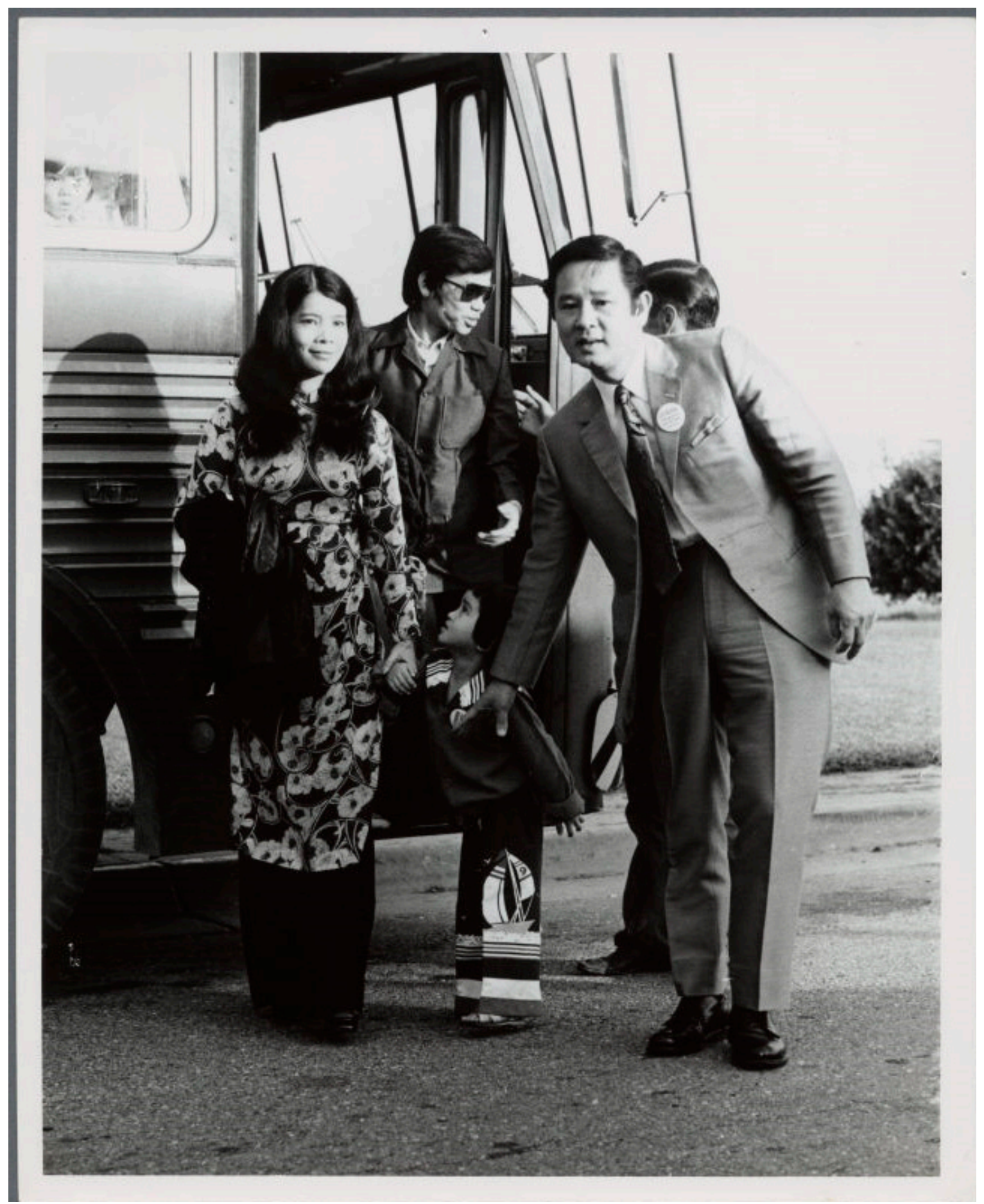

Figure 1. "Couple with child coming off a bus. Fort Chaffee (Ark.)".

Scholars of race and migration have demonstrated that immigration control practices at the border and through the law have produced sexuality, gender and race, and class identities through various procedures and classificatory schemes (Luibhéid 2002, p. xxii; Ngai 2004). While these concerns would appear to be related to the sociology of immigration, its sub-field of assimilation studies on the other hand has tended to focus on the ways that migrants who have successfully crossed the border have integrated economically (Coutin 2015). The practices of refugee management and the knowledge regimes that are simultaneously produced are not neutral, but intimately tied to the United States as an imperial white-supremacist settler-nation. Rather than pre-existing categories, refugee, 
immigrant, and Asian as identities and subject positions are generated through various deployments of and interactions with power, including sociological knowledge as disciplinary configurations of power (Zinn 1990; Collins 1998). What was the effect of framing Vietnamese refugees as families in studies of integration? In this essay, I put the emphasis on power from race and migration studies in conversation with assimilation to situate the construction of Vietnamese refugees in integration-based ${ }^{4}$ studies (FitzGerald 2014) and refugee resettlement within the governmentality of immigration, demonstrating how economic integration is mapped racially through family.

Feminist sociologist Dorothy Smith has argued that dominant sociology produces objectified knowledge that elevates its own forms of knowledge over the standpoints of the marginalized. As a practice, sociology emerges from and is complicit with the "relations of ruling" (Smith 1990). Drawing from feminist science studies and Foucauldian analyses of power, this essay contextualizes how power/knowledge embodied in surveys and social science studies of refugees produce the social relations they purport to describe, naturalizing Vietnamese refugees as a category of immigrant and upholding refugee integration via proximity to whiteness and heteronormativity. Assessments and knowledge about the economic wellbeing of migrants and refugees not only describe, but also situate these populations within class, racial, and ideological hierarchies and "reproduce the nation as heteronormative and national belonging as contingent on heteropatriarchal family forms" (Ferguson 2004; McNeill 2010, p. 60). ${ }^{5}$

In this essay, I first situate the role of sociological knowledge in the Cold War Orientalist project of containment and integration, arguing that the anti-Communist sentiments towards Asia manifested in a paternalistic desire to educate and incorporate Vietnamese refugees as Americans through a model of governance rooted in family. I then conduct a reading of Vietnamese resettlement surveys with the Moynihan Report as emblematic of a specific discursive practice of family, arguing that assimilation was made possible through the negation of the racial family. Vietnamese refugees are positioned against the black family as the exemplar of "downward assimilation," as policy makers and sociologists argue that family-based cultural values are the source of successful refugee integration. Thereafter, I follow the negation of the racial family in two canonical studies of Vietnamese refugee integration in the 1980s and the 1990s. Taken together, these studies reveal how refugee integration was premised upon sociological knowledge and the construction of Vietnamese families as distinct from the pathology of blackness.

\section{Sociological Containment: Race and the Normalization of Vietnamese Refugees}

The refugee family as a unit of analysis emerges at the nexus of domestic transnational considerations of the refugee regime as an apparatus in conjunction with, rather than as distinct from US aims to maintain control of economic markets and assert global hegemony during the Cold War. Throughout this period, the backlash against collective movements to secure rights along the lines of race, gender, and sexuality was consolidated at the site of family. The Great Society reforms were an attempt to make the heteronormative family the solution to socially generated problems such as poverty through a revival of "bread winner liberalism" embodied by "the white middle-class nuclear family headed by a patriotic and heterosexual male" (Self 2012).

Migration has historically been a site of production and regulation of family formations. Though family reunification ${ }^{6}$ (Reddy 2011, p. 161) had been at the heart of immigration policy since the advent of federal management in the late 19th century, the Hart-Celler Act, (the Immigration and Naturalization Act of 1965, hereafter INA), codified this preference in immigration policy ${ }^{7}$ (Luibhéid 2002, p. 2). The state's investment in heteronormative reproduction is encoded definitionally, with family described as "a cultural unit which contains a husband and wife who are the father and mother of their child or children" (Schneider 1980, p. 33). Against a backdrop of over 80 years of Chinese exclusion and isolationist, anti-immigrant and anti-Asian policies, the US welcomed Vietnamese refugees as the largest population of Asian migrants in history (Madokoro 2016). As a 
moment of acceptance and positive racialization, the depiction of and knowledge about Vietnamese refugees conforms to Michel Foucault's assertion that power is not exclusively repressive, but also that it is productive:

What makes power hold good, what makes it accepted, is simply the fact that it doesn't only weigh on us a force that says no, but that it traverses and produces things, it induces pleasure, forms knowledge, produces discourse. It needs to be considered as a productive network which runs through the whole social body, much more than as a negative instance whose function is repression. (Foucault 1980, p. 119)

Rather than viewing this radical change of heart as a contradiction, situating Vietnamese refugees as a Cold War family formation, reveals how the Cold War Orientalism as a project of knowledge and representation informed their reception.

The Cold War is widely acknowledged as theatre for the actual and ideological war of communism versus anti-communism through the logic of containment. While the United States shored up its military and economic forces to expand capitalism across Asia to combat the imagined hold of the USSR, domestic Cold War imaginaries flourished, producing bipolar frames of the political, economic, and social world (Klein 2003). Christina Klein has argued that the rise of cultural productions about Asia and Asians in middlebrow culture from 1945 functioned as ways to imagine and build affective relationships (winning hearts and minds) between Americans and Asians abroad and generate broad support for the war effort. Within this social context of imagined intimacies and affects, I read the inscription of Vietnamese refugees as normative potential citizens through the frame of sociology as containment. Sociology of immigration delineated the sites and objects of its study as a "tradition of occidental literary and scholarly interest in the countries and peoples of the East" reflective of Orientalism's relationship to American colonialism and imperialism (Lowe 1991, p. 3). Containment alone does not explain the project of incorporating Asia that was part of the capitalist expansion of the war. Rather than focusing solely on the logic of otherness and outward force of empire in the well documented discourse of containment, Christina Klein offers Cold War Orientalism as both containment and integration: Dual imaginaries shaping US policy towards Asia in this moment, "working through a logic of affiliation as well as through one of difference" (Klein 2003, p. 16). ${ }^{8}$ Reading the study of Vietnamese refugees-turned immigrants to America through these dual global imaginaries, we can see how the outward forces of an "educational" crusade against communism are turned inward towards these yet-to-be American subjects through a logic of sentimental and sociological inclusion, a feeling of kinship from which African Americans have historically been excluded (Eng 2010). Rather than waging a battle to win the hearts and minds of Asians in Asia, refugee resettlement brought those Oriental others to the United States to be trained in modes of democracy, freedom, and Americanness. Klein argues that the discourse of "family ties as political obligation" was critical in facilitating American adoption of Asian children through the image of mixed-race families as a form of postwar integration. The family frame provided a mode of overcoming racism while maintaining US foreign policy aims in Asia, as it symbolically reflected a social order with an accepted hierarchy (parents over children) where (West versus non-West) difference could be maintained (Klein 2003, p. 146). Through the logic of containment and integration, the elevation of family as a preferential category for immigration is significant for reinventing the ways the nation casts its subjects as productive units under capitalism, both unifying these subjects as tied to America and maintaining the internal hierarchies which shape racial difference. ${ }^{9}$ The racial, class, gender, and sexual project (Omi and Winant 1994, p. 56) ${ }^{10}$ of self-sufficiency (Ong 1993; Palumbo-Liu 1999, p. 240) ${ }^{11}$ embodied in the notion of family reunification has materially and metaphorically re-entrenched the notion of an ideal and idealized American family, re-establishing the contours of belonging through kinship and marriage simultaneously inscribing heteronormativity and Anglo and European culture as the norm. Vietnamese refugees and the excesses of the war were contained through social science knowledge narratives of integration. 


\section{Assimilation as (Racial) Progress Narrative}

In 30 April 1975, the "Fall of Saigon" marked the end of the US involvement in the Vietnam War. Between May and December of 1975, 130,000 Vietnamese refugees arrived and were dispersed across four domestic refugee camps in the United States. The arrival of Vietnamese refugees was met with public distrust and nativist doubt; a New York Times reader poll in 1979 reported that $62 \%$ opposed the admission of additional refugees (Montero and Judith 1979). ${ }^{12}$ Refugees arrived just as collective social welfare policies were disappearing, to be replaced by neoliberal individualism under Republican leadership. The economic exigencies of managing hundreds of thousands of Vietnamese refugees posed a challenge to a declining welfare state. Anxieties over poverty and racial inequality collided with a large foreign Asian population, most of whom arrived as dependents of the state.

Contemporary sociology bears the traces of the Chicago School's examination of social problems tied to the arrival of immigrants and Robert E. Park's cycle of race relations. This classical assimilation theory argued that immigrants would eventually assimilate to their new homes based on examination of European immigrants in urban centers on the east coast. Rooted in conceptions of ethnicity as mutable behavior, these theories held that prejudices would be overcome as newcomers adapted to American behaviors and values. As the reduction of race to ethnicity did not do away with racial discrimination, two alternative models emerged to reflect divergent experiences between the early 20th century white migrants and black Americans and post-1965 migrants of color. Downward assimilation referred to the experiences of the "underclasses," while segmented assimilation theory attempted to explain the diversity of migrant experiences, preserving the possibilities of downward, upward or partial integration (for an overview, see: (FitzGerald 2014).

The pathological families of Puerto Rican, Mexican American, and African Americans were blamed for the downward assimilation of black and Latinx populations in the 1960s (Briggs 2002). The "unstable" families that populated the culture of poverty thesis became the focus of intense scrutiny offering up the racial family as the site of intervention for poverty and other social ills, diverting attention away from the legacies of colonialism, racism, sexism, and classism. The narrative of failure which racialized immigrants and people of color as unassimilable and unable to incorporate American values manifested as a pathologizing of sexual difference (Briggs 2002; Shemak 2011). ${ }^{13}$ The racial family designates a category of social relations rooted in white supremacy, rather than the actual experience of families of color which may or may not be heterosexual, but due to their subjugated positions can never be heteronormative. It is everything that the American family is not: Not white, disorganized, hypersexual, unmarried, and poor.

In her discussion of Korean War brides, Grace Cho argues, "Sociologists commonly use assimilated interchangeably with honorary white, but there is no corollary of 'honorary black' status, thus reifying whiteness as the benchmark of assimilation into the United States ... blackness is always present as the shadow of honorary whiteness" (Cho 2008, p. 132). As foundational structures in the material world and the sociology of immigration's intellectual project, white supremacy and heteronormativity inform resettlement as a violent project of assimilation to the normative values of whiteness (Du Bois 1897, pp. 12-13). More than a theory, Catherine Ramírez argues that assimilation is a master narrative and a negotiation of national boundary. Challenging the notion that assimilation and racialization are separate processes, where white populations assimilate, and others are racialized Ramírez argues that assimilation itself is a process of racialization where noncitizens and people of color are incorporated, but as outsiders within (Ramírez 2020, p. 15). It is to this pre-existing field of assimilation, with its racial and sexualized inscriptions of belonging, that Vietnamese refugees became subjects of the study. In the wake of a failed war, sociological knowledge offered a narrative of successful assimilation, rooted in a normative family.

The Moynihan Report and the INA are two well-examined sites for interrogating the state's relationship to the family as racialized through capitalist self-sufficiency. "The Negro Family: A Case for National Action" published in March of 1965, by Daniel Patrick Moynihan, as the assistant secretary of labor outlined what he believed was the best course 
of action for African Americans, since, the passage of the 1964 Civil Rights Act meant that "demand of Negro Americans for full recognition of their civil rights was finally met". The report focused on unemployment and female-headed households, famously vilifying the black family, specifically the black matriarch as the cause of the breakdown of the black community (Moynihan 1965, p. 30). In the context of the passage of civil rights legislation, the report signaled that "the end of governmental responsibility marked the beginning of family responsibility, hence personal responsibility" (Ibrahim 2012, p. 49).

While celebrated as opening the door to migration from the Third World, the INA was initially meant to preserve the racial makeup of the United States (Reimers 1985, pp. 72-73). The family reunification provision of the act created openings beyond numerical limits for the family members of American citizens, who after four centuries of exclusionary and isolationist immigration policy, meant Europeans. As an officially anti-racist policy, the INA restored the national identity of the United States as a nation of immigrants in the aftermath of decades of racist and anti-immigrant isolationist policies. The prototypical American family in this moment had immigrant roots, but was distinctly not black.

From 1975-1984, the US government, through the Department of Health Education and Welfare (HEW), hired a research firm, Opportunity Systems Inc. (OSI) to conduct surveys of refugee resettlement. ${ }^{14}$ The longitudinal studies contacted the same sets of families and heads of households via telephone. Refugee homes and families became sites for the production of knowledge through mail and telephone follow-ups that were repeated every 60-90 days from 1975 to at least 1984 (11th Wave Survey). ${ }^{15}$ These quarterly studies of the refugees which were meant to ensure their successful adaptation, constructed a body of official knowledge commissioned by and presented to the state in various reports, through a regime of continual surveying and surveillance of Vietnamese refugees.

The aim of the OSI surveys was to determine how quickly refugees achieved economic self-sufficiency and assess problems with resettlement. OSI surveys counted refugees, organizing them by household, age, gender, family size, income, and employment status, centering the male head of household as informant for the surveys. The reports focused on economic opportunity to provide evidence that the refugees did not constitute economic burdens through dependency on public assistance. While not captured under the umbrella of the War on Poverty, the focus of OSI surveys reflect the concerns and methods of earlier antipoverty research to solve the issue of poverty through modeling "social mobility" based on fixed categories of "culture," rather than larger structural analysis of the material conditions of poverty in the first place. ${ }^{16}$ The surveys produced a circular logic that situated the absence of the male head of household as both the cause and effect of poverty, reinforcing the heteronormative family unit as dependent on a male head of household.

The singular focus on economic efficiencies reinforced traditional middle-class ideals of self-sufficiency in line with neoliberal political and economic shifts from the mid to the late 1970s. The first six wave surveys from 1975-1979, argued that refugees did not constitute economic burdens and that: "th[e] findings are consistent with the increasing rate of employment and overall progress toward self-sufficiency" (Montero 1979, p. 52). Heads of household in the First Wave (October 1975) survey held more white-collar jobs than subsequent cohorts, though most experienced under employment: $60.6 \%$ of Vietnamese who held white-collar jobs in Vietnam now worked blue-collar jobs, and only $20 \%$ of former professionals were able to secure professional level employment in the United States (ibid, pp. 39-41).

The emphasis on employment echoes the Moynihan Report's calculus of unemployment and the black family's inability to incorporate into American society 10 years prior. And yet, when read side by side, the HEW and the Moynihan report draw drastically divergent conclusions about welfare use and female employment for Vietnamese versus African American women. Black pathology is defined through deviant female sexuality and deviant economic participation, while Vietnamese success is defined through adherence sexual norms, but not economic ones. 
For Moynihan, both welfare use and women's workforce participation signaled pathology for African American families. Connecting economics, geography, and nonheteronormative family arrangements that included female heads of household, the Report had argued that "at the center of the tangle of pathology is the weakness of the family structure" (Moynihan 1965, p. 28). The supposed social disorder of the black community would be accomplished by saving the patriarchal family structure itself.

The First Wave Report indicated 291 women as heads of household. These female heads reported $37.3 \%$ not being in the labor force, with $62.7 \%$ in the labor force (Opportunity Systems, Inc. 1975, Table 1). One hundred ninety four of 1122 women over 14 years old who were household heads, $53.7 \%$ were employed and $46.3 \%$ unemployed (ibid, Table 2). Other tables chart federal assistance use over time by type of sponsor: Individual, family, group or no sponsor, but do not differentiate between female and male headed households. Of the 1570 heads who responded to the question of "employment status of heads of household" $57.1 \%$ were employed and $26.5 \%$ were unemployed, with the remaining $16.4 \%$ not in the labor force.

Fourteen percent of black female headed households were receiving Aid to Families with Dependent Children (AFDC). According to Moynihan, this signaled a "steady expansion" of its use and was a measure of "the steady disintegration of the Negro family structure over the past generation in the United States" (Moynihan 1965, p. 12). ${ }^{17}$ While ORR data does not compare female to male heads, the fact that $46.3 \%$ were unemployed would indicate that support was being sought or obtained outside of employment. The First Wave Report framed public assistance use in negative terms, as " $60 \%$ of the refugee families reported that they were not receiving any type of federal assistance". This indicates that the fact that $40 \%$ of families that are on public assistance is not characterized by researchers for HEW as weakness tied to racialized family structure (Opportunity Systems, Inc. 1975, p. 21). The attempt to frame the number in terms of a majority number not receiving assistance can only be read as devoid of racial implications by reading economics as an apolitical discourse. The naturalization of the categories and the data allow for the repeated assertion of Vietnamese success. While the Moynihan Report had used the statistic that over one-quarter of black families were headed by females (21\% compared to $9 \%$ of whites) to castigate the breakdown of the family (Moynihan 1965, p. 9), no theorizations were offered to explain the fact that in the Vietnamese case female headed households constituted $18.5 \%$ or 291 of the 1570 household heads surveyed.

The first report indicates 39.3\% labor force participation, and 51\% employment status of females 14 years and older. By the second and third waves, there was no data for labor force participation, but a $70 \%$ employment rate for women over 16 . The fourth report to Congress by the HEW Refugee Task Force on 16 March 1976 drew on Second Wave Report data to report:

[Vietnamese population] had a strong work ethic. A high percentage of Indochina refugees is [sic] in the labor force. The high number of females in the labor force is significant, because the refugees have come from societies where women traditionally have not worked outside the home. This further suggests a strong desire among refugee families to become self-supporting. (HEW Refugee Task Force Report to The Congress 1976, p. 5)

In the first instance, black female workforce participation signaled the breakdown of the family. In the second instance, it signaled perseverance and self-sufficiency among the Vietnamese. The underlying assumption behind reading female workforce participation as evidence of success is rooted in a liberation narrative wherein Vietnamese women transcended their own cultural backgrounds, where women did not work outside of the home to enter into the workforce. This interpretation of waged work as anything other than survival is only possible through Orientalizing of Asian families. By constructing Vietnamese families as traditional and patriarchal, where women do not participate in waged labor outside of the home, researchers argue for that "choice" to work is evidence that Vietnamese women are able to adapt by overcoming tradition to join the workforce. 
This dual move situates the United States as a place where women have the freedom to choose work, obscures a long history of women's waged work as a site of racialization in the United States through the appropriation of the white feminist movement's demand for access to employment. This deployment of liberal feminism is then used to celebrate America as the site of freedom and progress for women, particularly those fleeing from communist regimes.

By late 1979, according to all measures deemed significant to HEW, refugee resettlement was a success, this despite the reality of downward mobility for Vietnamese in the workforce (Montero 1979, p. 39). This "refugee exceptionalism" — the discursive removal of refugees from discourses of the underclass, argues that eventually refugees would achieve successes promised by liberalism, even though empirical evidence disproved this (Tang 2015, pp. 14-15). The report's last claim less than 1 year after the initial resettlement, based on a $40 \%$ rate of Vietnamese welfare use coupled with a moral responsibility to help refugees made it possible to argue that refugees were becoming self- sufficient ${ }^{18}$ The largely intact nature of early Vietnamese families enabled researchers to construct Vietnamese families, and this in proximity to middle-class white family structures. In the context of post-civil rights pivot towards official state anti-racisms, racial discourses did not disappear but were revised into discussions of culture and behavior (Melamed 2011). Successful refugee resettlement was deployed not only to uphold US-dominance internationally, but also domestically in the war against the Civil Rights Movement.

\section{Refugee Family Values}

In popular media from the 1980s through the 1990s, news outlets depicted the refugees as yet another immigrant success story. Analyzing Newsweek and Time Magazine stories, sociologist Nazli Kibria highlights the emphasis on the positive qualities of Vietnamese families, and their compatibility with American culture. Kibria reports, "Popular media reports further suggest that what is responsible for the alleged miraculous economic progress of Vietnamese Americans is the cultural quality of their family life ... within the stable, traditional, and hierarchical confines of their families, the Vietnamese are taught that cultural values that are integral to their success" (Kibria 1993, p. 7). Kibria notably contributes to an important divergent analysis of Vietnamese families, which does not reify a model family. In the media, stories again and again tied the root of Vietnamese success to their determination to adapt, their culture, and family structure (Blake 1981). Canonical social science research crystallized this assertion through numerous studies and reports on refugees in the decades following their arrival in the United States. The representation of the refugees in news magazines, much like in sociology, constituted a project of US multicultural liberalism that emphasized individualized success. In the context of economic downturns, the focus on the family as an intact unit has yielded incomplete and contradictory explanations about the reasons for refugee economic success. The realities of these successful Vietnamese refugee families were less important than the representation which was constructed against the racial family in a new context: The Reagan administration's War on Drugs attacks black and brown families which produced and relied upon racialized imagery of crack abuse to shore up support for criminalization and increased incarceration (Provine 2007).

While the 20-year period of Southeast Asian refugee migration (1975-1995) may be marked by different waves of refugees bringing with them various educational and economic as well as ethnic backgrounds, it is characterized by a continuity produced through the state's approach to refugee resettlement. ${ }^{19}$ The passing of the 1980 Refugee Act represented a shift away from the ad-hoc policies of 1975, but nevertheless reinforced the original goals of "effective resettlement" or economic self-sufficiency which was to be achieved as rapidly as possible. The cohorts that followed from the end of 1978 to the early 1980s-the so-called "boat people" did not flee in planes or arrive in reception camps in the United States. They were poorer refugees, with fewer in-tact families, who were provided fewer resources for resettlement and shorter support timelines than earlier 
arrivals (Robinson 1998, p. 134). ${ }^{20}$ By 1980, the United States also saw the arrival of larger numbers of Central Americans, Black Mariel Cubans, and Haitian asylum seekers in Florida, coupled with domestic inflation and recession. According to sociologist Rubén Rumbaut, "The confluence of these events in turn contributed to an accompanying political climate of intensifying nativism, racism, xenophobia, and 'compassion fatigue'" (1995). The economic context produced a bifurcation within the discursive field that distinguished between the first wave of largely well-to-do Vietnamese refugees and later more heterogeneous cohorts of refugees, resulting in a distinction between the earlier refugee success.

As a continuation of initial resettlement surveys, these newer sociological studies strongly incorporated Southeast Asians into existing frameworks of immigration. In these studies, refugees were repeatedly referred to as new immigrants. In addition, the image of the idealized Vietnamese family as nuclear and intact-the self-evidently beautiful Vietnamese families that arrived in the first wave- -had been replaced by the view of the new arrivals as rural, resource poor, and coming from broken families. Casting them as immigrants, they were folded into narratives of assimilation and integrated into the state. The actual foundation of this particular migration history-a violent and unnecessary military intervention - gave way to narratives of making it in America. From the 1980s onward, resettlement studies such as Zhou and Bankston's reiterated Park's cycle of assimilation $(1998,220)$. The title of a volume (one of many) on the refugees exemplifies this: Refugees as Immigrants (1985). Editor David Haines introduced the volume as research on the adaptation of these refugees as just one more group in the long line of immigrants to the United States. By collapsing the refugees into the immigrant narrative (which is characterized by choice and eventual incorporation), Haines et al. inadvertently erased the conditions that generated their movement to the United States in the first place. As time passed, sociologists shifted their emphasis to the second generation. The generational narrative is important to ethnic succession (Ong 2003, p. 3) 21 $^{21}$ and the telos of immigrant integration, as the early struggles of the first generation made way for a focus on their children. Whether or not the arrivals were able to achieve successes against the reality of language barriers, racism, and underemployment, an optimistic focus on their children would characterize resettlement as a success.

\section{The Boat People-The Generational Narrative in Caplan and Zhou}

In 1981, the Office of Refugee Resettlement contracted sociologist Nathan Caplan for several policy reports. His contributions included studies of refugee self-sufficiency that would have direct consequences on Reagan-era policy agendas regarding resettlement. Caplan, Marcella Choy, and John Whitmore began a five-site survey of Southeast Asian refugees and in 1989 published The Boat People and Achievement in America: A Study of Family Life, Hard Work, and Cultural Values. The study analyzes Vietnamese, Lao, Cambodian, and ethnic Chinese populations, and offers a series of generalizations about the second wave of Southeast Asians as though they formed a homogeneous population with shared family structures. Today, the study by Caplan et al. has become canonical to Vietnamese and second-generation immigrant studies.

The presumption of refugee success informed research questions crafted by Caplan et al. The introduction to the volume establishes "cultural patterns" as indicative of the success predicted by the research, despite the pan-ethnicity of this cohort of immigrants:

The refugees have now begun to share in the Asian-American success stories we have become accustomed to find reported in the news media. They have made these accomplishments despite having entered this country only with what was on their backs ... Their only resources were the cultural patterns of their societies ... With this living framework, they were ready to pursue their lives in new circumstances (4).

Caplan et al. studied groups of Lao, Cambodian, and other "Indochinese" refugees together in order to argue that "culture" and "family" are the roots of success, drawing upon the trends in the sociology of immigration that take for granted the desirability of assimilation and adaptation to American society $(42) .{ }^{22}$ Caplan et al. evaluated cultural 
values, drawing definitions from Southeast Asian literature, history, and anthropology. In hierarchized value matrices, they identified three categories of significance: First, "culturewide Confucian-Buddhist" values, second "family-based orientation" or family support and finally, individually- based goals (Caplan et al. 1989, p. 42). By defining households as nuclear families or extended family units with a nuclear core, and applying this formulation of family to their values matrix, the study by Caplan et al. affirmed the heterosexual family unit as central to Vietnamese and Southeast Asian success in the areas of educational, and economic achievement.

The Boat People is based on interviews of second wave refugees, ${ }^{23}$ a more diverse cohort than the first wave. Since the boat people or second wave were relatively less intact as family units (sometimes family members sent one person first, others were split up by the dangerous conditions of their flight by foot and boat, whereas the first wave were mostly transported together by US military aircraft), less educated, poorer, more rural, illiterate, and had less English proficiency, policy makers revived concerns of dependency on welfare and other state programs. Moreover, red flags were raised concerning the assimilation of the second wave given that many of these refugees were resettled in largely poor Latino and black neighborhoods (unlike some wealthier first wave refugees). The resettlement of many of these later waves of refugees was based on cheaply secured government housing in underdeveloped areas (Tang 2015). The renewed fear of dependency, and the renewal of the culture of poverty thesis, made experts worry that the refugees would adopt the bad habits of their impoverished neighbors.

Despite the disparity in family structures between the first wave and subsequent waves, the Caplan study argues that a core set of traditional values and the cultural significance of family to refugees would lead to inevitable success. Caplan et al. "place[d] great confidence in [their] explanation of the role of cultural values as implemented through family life-style...these values of practical significance to achievement are, if not identical, congruent with what have been viewed as mainstream middle-class American beliefs about getting ahead" (Caplan et al. 1989, p. 178). These values were congruent with "traditional," hegemonic white American values in contrast to the "others" who "choose" to remain incompatible with the mainstream. As a narrative about immigrants in America, the study pits immigrants against the black community, reinforcing the myth of meritocracy of the American society, and argues that not only have the refugees earned their place (unlike their black and brown peers), but they have also "shown the strength of the system by their ascendency at a time of severe economic recession, when few would have expected them to succeed and some questioned this country's capacity to support them" (ibid, p. 150). Based on area studies research about Southeast Asia, Caplan identified three main dimensions of the cultural values of Southeast Asian refugees: (1) Education and achievement; (2) A cohesive family; and (3) Hard work (Caplan et al. 1989, p. 42). Area studies-based approaches to constructing a "Southeast Asian culture" stem from early Cold War methodologies of social science. If area studies is about regionalization, spheres of influence and sovereignty, then the legacy of Southeast Asian Area studies for refugees in the United States requires their rendering as compatible with U.S. capitalism via American cultural values (Barlow 1993). Accordingly, Southeast Asian "ways of life" apparently rooted in "family-based orientation characterized by reciprocal support and respect featur[ing] centrally in their formulation" (Caplan et al. 1989, p. 42). For the study headed by Caplan, the family and its traditions and "core values" constituted the site of salvation for the refugee.

The authors of these studies employ instrumentalist understandings of family. As Caplan et al. write, "The family is the major vehicle by which the Indochinese define and come to grips with the world they face" (ibid 178). Family structures are variables that lead to increased social capital and are necessary to support economic success in a moment when increased federal investment in communities and families has predetermined failure for other minority groups. When treated as an independent variable that can be used to predict outcomes for refugee adaptation, the family is called upon to reinforce the aims 
of the state and reproduce whiteness and possessive individualism. The discourse on the family in traditional sociology is racialized and ideological. While the Johnson era was characterized by white liberal policies of inclusion, the Reagan era oversaw the reanimation of conservative understandings of race and the family. In family sociology, the failure to recognize race as a foundational technology determining social structure relegated race and ethnicity as secondary elements of culture for explaining the particularities of experience. This contributed to the disavowal the ideological and material impact that race and ethnicity have on shaping life opportunities, thus the narrative of assimilation, "focused primarily on the apparently universal yearning for the freedoms and comforts of middle-class life in the West" (Rowe and Berg 1991, pp. 7-8).

Zhou and Bankston's work has become canonical in contemporary sociology focused on the assimilation process. In their award-winning study, Growing Up American (1998), sociologists Min Zhou and Carl Bankston III continue their examination of the surprising successes of Vietnamese refugees. Focusing on the adaptation of the children of Vietnamese refugees in the community of Versailles Village, New Orleans, they build upon earlier research such as Caplan et al. (see also: Haines 1985) that asserted the significance of ethnic values to adaptation. The authors extend the argument to community and wider kinship networks to demonstrate that the social capital available to Vietnamese families vis-à-vis a larger Vietnamese community is critical to answering the question of why Vietnamese youth are successful in the face of other minority delinquency.

The authors maintain that the cultural values of the Vietnamese were a source for positive assimilation. They also situate Vietnamese families within a larger context of community to which they attribute the significance of cultural transmission and tradition. As with The Boat People, they concluded that their findings, "which are consistent with prior research on the Vietnamese refugees, indicate a positive relationship between the acceptance of traditional family values and school performance (Zhou and Bankston 1998, p. 223)." Here, children of refugees were framed as second-generation immigrants: The benefits of assimilating to American society and cultural values were unquestioned. The authors argued that the community as an extension of the family as a support system was key to their success where other racial minorities had failed. Through successful assimilation, the Vietnamese became immigrants bound for incorporation into the American body.

The authors' research site-Versailles Village, Louisiana-is significant due to the subjects' proximity to other minority groups, primarily black families (Nopper 2014). It became the perfect test case for examining the "positive" cultural values of the Vietnamese that would lead to successful assimilation including occupational and educational achievement. These are the same values that the researchers juxtapose with the "negative" cultural values of their underclass neighbors:

Vietnamese children are pushed toward educational success by their parents but at the same time are pulled by the oppositional youth culture that surrounds them ... If they strive to meet their parents' expectations for academic achievement they are likely to be ostracized as 'uncool', 'nerdy', or 'acting white' by their American schoolmates, mostly members of racial minorities. If they submit to peer pressure ... they are likely to adopt the cultural ways, including the language and behavior, of the underclass. (Zhou and Bankston 1998, p. 221)

Demonizing the cultural traits and behaviors of black and brown minorities in the community and constructing them against the traits and behaviors of Vietnamese Americans, the authors conceptualize structural inequality as a matter of individual poor choices. By relying on conservative ideologies about "deficient" versus "functional" families, Zhou and Bankston asserted that it was imperative that Vietnamese youth be inculcated with strong traditional values so that they do not fall prey to the cultural attitudes of disrespect and delinquency that their black and Latino neighbors embody:

Becoming integrated into a low-income, disadvantaged neighborhood means becoming part of a social group that is alienated from middle-class America 
and that integration offers few opportunities for becoming part of the American mainstream ... Through their families, young people become part of the ethnic community, and the ethnic community enables them to bypass the troubled, marginalized neighborhood that surrounds them and to concentrate on the chief opportunity offered them, public schooling. (ibid, p. 229)

The difference between the pre-existing marginalized community was not the absence of ethnic community, but rather the Vietnamese families and their embrace of heteronormativity: "Though very poor, the Vietnamese displayed one characteristic not usually associated with poverty: the overwhelming majority $(81 \%)$ of families in Versailles Village were married-couple families" (ibid, p. 81).

Women as heads of households function as an indicator of social break-down and social disorder and therefore are central to scholarly depictions of refugee success. Zhou and Bankston cited a lower number of female headed household- $6 \%$ for Vietnamese families versus 55\% for African Americans. They conclude that even though these refugees resided in the poorest neighborhoods and had few opportunities for skilled labor, the intact and hierarchical family structure would be the antidote to future problems: "They might ... be able to overcome these [economic] limitations with the social capital formed in their intact families and their ethnic community" (ibid). Whereas Tang's "refugee exceptionalism" demonstrated that a dismissal of Southeast Asian poverty as a temporary condition justified inequality against other people of color in the ghetto, Zhou and Bankston's argument deploys exceptionalism as not only a raced, but also a heteronormative patriarchal structure (Nopper 2014, pp. 227-34). ${ }^{24}$

Although social scientists maintained their focus on economic conditions for refugees, the use of cultural explanations for success in The Boat People and Growing Up American constructed the Vietnamese family itself as the source of that success. Vietnamese refugees became the objects of analysis and the family became the unit of inquiry. Conclusions about good or bad family values were bases on broadly defined cultural values to explain how and why some racialized groups faced poverty while others did not. The listing of race, gender, and immigration status as descriptive cultural categories of analysis erased structural constraints that organize economic, social, and material resources (Zinn 1990, p. 73). Though the sociology of Vietnamese immigration purported to offer objective knowledge about the social determinants of economic inequality, it actually reproduced conservative explanations for poverty, redirecting the focus away from the role of the state in perpetuating structural inequality and towards the community's responsibility to "fix" bad cultural traits (Tang 2015, p. 60).

\section{Conclusions}

In this essay, I have attempted to demonstrate how sociology as power/knowledge functioned not only to erase the war, but as racialization and subject-formation, producing Vietnamese immigrants as successfully assimilated due to white-congruent family norms and values in contrast to the purported failure of African Americans to accord with the same family norms and values.

As a discursive practice, family and the notion of "traditional" values and "successful achievement" are not merely descriptive, but rather construct white, American heteronormative structure as the norm (Reddy 2005; Eng 2010). The basis of researchers' arguments about Southeast Asian achievement is essentially modernist: They establish modernity of supposedly inherent values held and lived by Southeast Asians, which promotes them to an assimilable status. Early arguments for refugee acceptance were articulated through Christian values made possible by appealing to the overrepresentation of Catholics in the first wave (Guerrero 2017, p. 62). For later waves, even their cultural and religious difference which was characterized by Confucianism and Buddhism was adapted to fit into American modernity by aligning hard work and respect with American capitalist values. Emphasizing the productive and regulatory function of "family" as a heteronormative-state bound unit reveals the operations of the state and the stakes of producing knowledge about 
refugees and their intimate lives. Sociology as a site of state power produced family "types" as either pathological or successful. In focusing on the emergence of the refugee family in this survey literature, I demonstrate how official knowledge of refugees was constructed in relation to racialized discourses of pathology based on the negation of the racial family. The overemphasis on economic success and self-sufficiency produced the Vietnamese as a privileged group of immigrants through a generational narrative of eventual incorporation and argued that they have been successfully included in American society due to their compatibility with pre-existing American values.

This incorporation affirms the myth of the United States' benevolence and is used to discredit structural critiques of inequality, simultaneously distancing Vietnamese refugees as a population that is in the United States due to failed war, reinforcing domestic racism and undermining the impacts of assimilation as a violent process of subjection. Additionally, as critical refugee studies scholars have argued that the metrics for measuring success are ideological maneuvers designed to allow Americans to move on from the war. I have demonstrated that state-sponsored discourses of the racial family have defined it in relation to the heteronormative family as a unit necessary for liberal inclusion into the nation-state and the political and economic system of capitalism.

Funding: This research received no external funding.

Institutional Review Board Statement: Not applicable.

Informed Consent Statement: Not applicable.

Data Availability Statement: Not applicable.

Conflicts of Interest: The author declares no conflict of interest.

\section{Notes}

1 The Indochina Refugee Assistance Act mandated quarterly reporting on refugee resettlement.

2 The fact of their forced or involuntary migration constructs refugees as deserving of support services that immigrants who supposedly migrate as a result of economic choices are not entitled to, but also denotes a victimized or traumatized status as an additional barrier to overcome.

3 Lee argues, the model minority is a Cold War myth that functions not only to discipline Asian and Black communities, but also to ward off the red menace of communism, black menace of miscegenation and white meance of homosexuality.

4 I use the terms integration and assimilation interchangeably. Sociologist David Scott FitzGerald, explains that while integration purportedly imputes neutrality of values and norms over assimilation, in practice there is no difference, and choice of terms usually only reflects regional or political socializations.

5 Tanya McNeill deploys Roderick Ferguson's queer of color analysis in their examination of the Personal Responsibility and Work Opportunity Reconciliation Act (1996) and the Healthy Marriage Initiative (2002) as national codifications of heteronormativity. The connections between the morality of whiteness, heterosexuality and the patriarchal Christianity family have a long history in the United States and the West, justifying imperialism and colonial civilizing missions, though further examination of this is beyond the scope of this paper.

6 Chandan Reddy explains that "family reunification" as a post 1965 immigration category "enabled state power to create heteropatriarchal relations for the recruitment and socialization of labor while simultaneously justifying the exclusion of immigrant communities from state power through a liberal language of US citizenship as the guarantor of individual liberty and sexual freedom."

7 Luibheid calls attention to the 1890 Immigration Act in order to demonstrate a longer legacy of family's significance to immigration policy: "nothing in this act shall be construed as prohibiting any individual from assisting any member of his family or relative or personal friend to migrate from any foreign country to the United States for the purposes of settlement here."

8 This can be further extended in her analysis of middle brow logic of "family ties as political obligation," as a frame for articulating articulated through the logic of adoption and mixed-race families. Here she traces the emergence of family discourse as an explanatory frame for US-Asia relations, valued for its ability to both unify and preserve hierarchies (i.e., age, gender) best exemplified in her quotation of JFK's 1956 speech to the American Friends of Vietnam: "If we are not the parents of little Vietnam ... then surely we are the godparents. We presided at its birth, we gave assistance to its life, we have helped shape its future ... This is our offspring - we cannot abandon it, we cannot ignore its needs" (ibid., p. 189).

9 Luibheid makes this connection in a footnote: "The use of the heterosexual family as an instrument of racial purpose, evident in the 1965 [Immigration and Naturalization Act] also cropped up in Daniel Patrick Moynihan's The Negro Family ... released the same year" (178 fn109). 
10 Sociologists Michael Omi and Howard Winant define racial projects as "simultaneously an interpretation, representation, or explanation of racial dynamics, and an effort to reorganize and redistribute resources along particular racial lines". They "do the ideological 'work' of making links" between structure and representation.

11 David Palumbo-Lui argues "self-sufficicency" as a goal reflects the state's desire to see economically independent (and therefore non-demanding) subjects produced at the end of the assimilation process, subjects able to perform in the circuits of production and consumption.

12 Question: “Do you approve or disapprove of the U.S. government's plan to double the number of refugees from Indochina admitted, to 14,000 a month?"

13 This argument made primarily in regard to Mexican and Puerto Rican migrants as well as Haitian and Mariel Cubans. Also, Roderick Ferguson's queer of color critique re-situates the production of queer of color (specifically queer black) identity within the conditions of transnational capital to demonstrate how the black woman and the black family was made to bear the contradictions of capital.

14 This period of data collection was mandated by the 1975 Indochina Migration and Refugee Assistance Act (PL 94-23), an Interagency Task Force (IATF) made up of twelve federal agencies, established to oversee the first years of evacuation and resettlement.

15 These surveys sometimes referred to as the Opportunity Systems, Inc. (OSI) wave surveys (for the agency that was paid to conduct them) were commissioned by the Department of Health, Education and Welfare, or simply named the survey by wave (first wave, second wave, and so on). These surveys are the first surveys of refugees since their arrival. The data from these surveys informed the annual report by the Interagency Task Force for Indochina Refugees which was submitted directly to Congress, as well as other social scientific analysis on the question of resettlement and adjustment.

16 One such example is The Socioeconomic Life-Cycle model developed by Otis Dudley Duncan and Robert Hodge (1963). In their assessment of male social mobility, the researchers developed a simple linear algebraic model based on white males to measure whether or not background such as race and father's educational level could be improved through interventions via education (Haveman 1987, p. 110).

17 The racialization of AFDC and the vilification of the Black family structure may be further explained by the fact that African American women had finally gained some access to welfare programs in the mid 1960s through War on Poverty reforms.

18 Montero publisbed his synthesis copies of the first five wave surveys. Collapsing the experience of the Vietnamese within the category of Asian American, Montero argued that successes of previous groups, such as the Japanese and Chinese (due to his ability to overlook discrimination and the fact of Japanese internment) had set precedents and expectations for Vietnamese to succeed. The first set of surveys on refugees was significant to the image of refugee self-sufficiency which was coupled with conservative backlash against the Great Society programs, that accelerated the decline of the welfare state. As the 1970s gave way to economic deregulation in the 1980s, the family unit would become a significant site to absorb the externalities of neoliberal restructuring.

19 After 1995, the United States ended sanctions in the form of the trade and communications embargo and normalized relations with Vietnam. This became the cut-off date for admission as refugees.

20 In 1980, the federal government reimbursed states 100\% of resettlement costs for 36 months, in 1981 it was reduced to 18 months.

21 "More a structure of beliefs than an empirical reality, ethnic succession is a set of expectations tat in a just a moral world, ethnic minorities will attain entry into the mainstream of American society through gains achieved in successive generations."

22 Later studies would reveal that the breaking up of the family structure resulted in the creation of a Southeast Asian "underclass". See: (Ong 2003; Tang 2015)

23 Though there is disagreement in the specific cut off between waves of immigration, it is generally agreed that those who did not experience US-based refugee camps, coming largely by boat versus airplane after the initial 1975 cohort are considered part of the second wave.

24 The authors' use of family and ethnicity as modes of social capital must be situated with the larger context of dominant cultural values in the United States. Nopper offers an in-depth discussion the model minority in Asian assimilation studies and an extended discussion of the site of Zhou and Bankston's study in Louisiana.

\section{References}

Barlow, Tani E. 1993. Colonialism's Career in Postwar China Studies. Positions: East Asia Cultures Critique 1: 224-67. [CrossRef] Blake, Patricia. 1981. Refugees: Safe Ashore at Last. Time (Chicago, Ill.) 117: 45-48.

Bradley, Mark. 2000. Imagining Vietnam and America: The Making of Postcolonial Vietnam, 1919-1950. New Cold War History. Chapel Hill: University of North Carolina Press.

Briggs, Laura. 2002. Reproducing Empire: Race, Sex, Science, and U.S. Imperialism in Puerto Rico. American Crossroads 11. Berkeley: University of California Press.

Caplan, Nathan S., Marcella H. Choy, and John K. Whitmore. 1989. The Boat People and Achievement in America: A Study of Family Life, Hard Work, and Cultural Values. Ann Arbor: University of Michigan Press.

Cho, Grace M. 2008. Haunting the Korean Diaspora Shame, Secrecy, and the Forgotten War. Minneapolis: University of Minnesota Press. Collins, Patricia Hill. 1998. It's All in the Family: Intersections of Gender, Race, and Nation. Hypatia 13: 62-82. [CrossRef] 
Coutin, Susan Bibler. 2015. Deportation Studies: Origins, Themes and Directions. Journal of Ethnic and Migration Studies 41: 671-81. [CrossRef]

Du Bois, William E. B. 1897. The Conservation of Races. Available online: https://www.gutenberg.org/files/31254/31254-h/31254-h. htm (accessed on 31 May 2021).

Eng, David L. 2010. The Feeling of Kinship: Queer Liberalism and the Racialization of Intimacy. Durham: Duke University Press.

Espiritu, Yên Lê. 2006. Toward a Critical Refugee Study: The Vietnamese Refugee Subject in US Scholarship. Journal of Vietnamese Studies (Berkeley, Calif.) 1: 410-33. [CrossRef]

Ferguson, Roderick A. 2004. Aberrations in Black: Toward a Queer of Color Critique. Critical American Studies Series; Minneapolis: University of Minnesota Press.

Finnan, Christine Robinson. 1981. Occupational Assimilation of Refugees. The International Migration Review 15: 292-309. [CrossRef]

FitzGerald, David Scott. 2014. The Sociology of International Migration. In Migration Theory: Talking across Disciplines. Edited by Caroline B. Brettell and James F. Hollifield III. London: Taylor and Francis, pp. 115-47. [CrossRef]

Foucault, Michel. 1980. Power/Knowledge: Selected Interviews and Other Writings, 1972-1977, 1st American ed. New York: Pantheon Books.

Guerrero, Perla M. 2017. Nuevo South: Latinas/Os, Asians, and the Remaking of Place, 1st ed. Austin: University of Texas Press.

Haines, David W. 1985. Refugees in the United States: A Reference Handbook. Westport: Greenwood Press.

Haveman, Robert H. 1987. Poverty Policy and Poverty Research: The Great Society and the Social Sciences. Madison: University of Wisconsin Press.

HEW Refugee Task Force Report to The Congress. 1976. Box 13, Ron Nessen Papers, Gerald R. Ford Presidential Library. Available online: https: / / www.fordlibrarymuseum.gov/library/document/0204/1511799.pdf (accessed on 31 May 2021).

Ibrahim, Habiba. 2012. Troubling the Family: The Promise of Personhood and the Rise of Multiracialism. Minneapolis: U of Minnesota P.

Kibria, Nazli. 1993. Family Tightrope: The Changing Lives of Vietnamese Americans. Princeton: Princeton University Press.

Klein, Christina. 2003. Cold War Orientalism: Asia in the Middlebrow Imagination, 1945-1961. Berkeley: University of California Press.

Lee, Robert G. 1999. Orientals: Asian Americans in Popular Culture. Philadelphia: Temple University Press.

Liu, William Thomas. 1979. Transition to Nowhere: Vietnamese Refugees in America. Nashville: Charter House.

Lowe, Lisa. 1991. Critical Terrains: French and British Orientalisms. Ithaca: Cornell University Press.

Luibhéid, Eithne. 2002. Entry Denied: Controlling Sexuality at the Border. Minneapolis: University of Minnesota Press.

Madokoro, Laura. 2016. Elusive Refuge: Chinese Migrants in the Cold War. Cambridge: Harvard University Press.

McNeill, Tanya. 2010. A Nation of Families: The Codification and (Be)Longings of Heteropatriarchy. In Toward a Sociology of the Trace. Edited by Herman Gray and Macarena Gómez-Barris. Minneapolis: University of Minnesota Press, pp. 57-85.

Melamed, Jodi. 2011. Represent and Destroy: Rationalizing Violence in the New Racial Capitalism. Difference Incorporated. Minneapolis: University of Minnesota Press.

Montero, Darrel. 1979. Vietnamese Americans: Patterns of Resettlement and Socioeconomic Adaptation in the United States. Westview Replica Edition. Boulder: Westview Press.

Moynihan, Daniel P. 1965. The Negro Family: The Case for National Action. National Capital Open Space Program. Technical Report. Washington: US Govt Print Off.

Ngai, Mae M. 2004. Impossible Subjects: Illegal Aliens and the Making of Modern America. Politics and Society in Twentieth-Century America. Princeton: Princeton University Press.

Nguyen, Mimi Thi. 2012. The Gift of Freedom: War, Debt, and Other Refugee Passages. Next Wave. Durham, North Carolina. London: Duke University Press.

Nopper, Tamara. 2014. Asian Americans, Deviance, Crime, and the Model Minority Myth. In Color Behind Bars: Racism in the U. S. Prison System. Edited by Scott William Bowman. Westport: Praeger, pp. 207-43.

Okihiro, Gary Y. 2014. Margins and Mainstreams: Asians in American History and Culture. Seattle: University of Washington Press.

Omi, Michael, and Howard Winant. 1994. Racial Formation in the United States: From the 1960s to the 1990s, 2nd ed. New York: Routledge.

Ong, Aihwa. 1993. On the Edge of Empires: Flexible Citizenship among Chinese in Diaspora. Positions: East Asia Cultures Critique 1: 745-78. [CrossRef]

Ong, Aihwa. 2003. Buddha Is Hiding: Refugees, Citizenship, the New America. Berkeley and Los Angeles: University of California Press.

Opportunity Systems, Inc. 1975. First Wave Report: Vietnam Resettlement Operational Feedback. Available online: http: / /library.bsl.org.au/bsljspui/bitstream/1/11635/1/steinb_occupational_adjustment_of_refugees_the_vietnamese_in_the_ united_states_chomi_357_1979.pdf (accessed on 31 May 2021).

Palumbo-Liu, David. 1999. Asian/American: Historical Crossings of a Racial Frontier. Palo Alto: Stanford UP.

Provine, Doris Marie. 2007. Unequal Under Law: Race in the War on Drugs. Chicago: University of Chicago Press.

Ramírez, Catherine Sue. 2020. Assimilation: An Alternative History. Oakland: University of California Press.

Reddy, Chandan. 2005. Asian Diasporas, Neoliberalism, and Family. Social Text 23: 101-19. [CrossRef]

Reddy, Chandan. 2011. Freedom with Violence: Race, Sexuality, and the US State. Perverse Modernities. Durham: Duke University Press.

Reimers, David M. 1985. Still the Golden Door: The Third World Comes to America. New York: Columbia University Press.

Robinson, Court. 1998. Terms of Refuge: The Indochinese Exodus $\mathcal{E}$ the International Response. Politics in Contemporary Asia. London and New York: Zed Books. 
Rowe, John Carlos, and Rick Berg. 1991. The Vietnam War and American Culture. Social Foundations of Aesthetic Forms Series; New York: Columbia University Press.

Rumbaut, Rubén. 1995. Vietnamese, Laotian, and Cambodian Americans. In Asian Americans: Contemporary Trends and Issues. Edited by Pyong Gap Min. Sage Focus Editions; v. 174. Thousand Oaks: Sage Publications.

Rumbaut, Rubén, and Kenji Ima. 1987. The Adaptation of Southeast Asian Refugee Youth: A Comparative Study. San Diego: Department of Sociology, San Diego State University.

Schneider, David Murray. 1980. American Kinship: A Cultural Account, 2nd ed. Chicago: University of Chicago Press.

Self, Robert O. 2012. All in the Family: The Realignment of American Democracy Since the 1960s. New York: Hill and Wang, a division of Farrar, Straus and Giroux.

Shemak, April Ann. 2011. Asylum Speakers: Caribbean Refugees and Testimonial Discourse, 1st ed. New York: Fordham University Press. Smith, Dorothy E. 1990. The Conceptual Practices of Power: A Feminist Sociology of Knowledge. Northeastern Series in Feminist Theory; Boston: Northeastern University Press.

Tang, Eric. 2015. Unsettled: Cambodian Refugees in the New York City Hyperghetto. Asian American History and Culture. Philadelphia: Temple University Press.

Montero, Darrell, and McDowell Judith. 1979. Poll on Refugees: Mixed Views. The New York Times, July 15. Available online: https: / / www.nytimes.com/1979/03/12/archives/refugees-making-it.html (accessed on 31 May 2021).

Thompson, Larry Clinton. 2010. Refugee Workers in the Indochina Exodus, 1975-1982. Jefferson: MacFarland and Company, Inc.

Zhou, Min, and Carl L. Bankston. 1998. Growing up American: How Vietnamese Children Adapt to Life in the United States. New York: Russell Sage Foundation.

Zinn, Maxine Baca. 1990. Family, Feminism, and Race in America. Gender \& Society 4: 68-82. 